\title{
OAK FORESTS TYPES OF Quercus humboldtii IN THE Guantiva-La Rusia-Iguaque CORRIDOR (SANTANDER-BOYACÁ, COLOMBIA): THEIR CONSERVATION AND SUSTAINABLE USE Tipos de bosques de roble (Quercus humboldtii) en el corredor Guantiva-La Rusia-Iguaque (Santander-Boyacá, Colombia): su conservación y uso sostenible \\ Título corto: Oak forests: conservation and sustainability
}

Keywords: Oak forest, management tropical forests, Oakconservation, sustainable use

Palabras clave: bosques de robles, manejo bosques tropicales, robles, conservación, uso sostenible

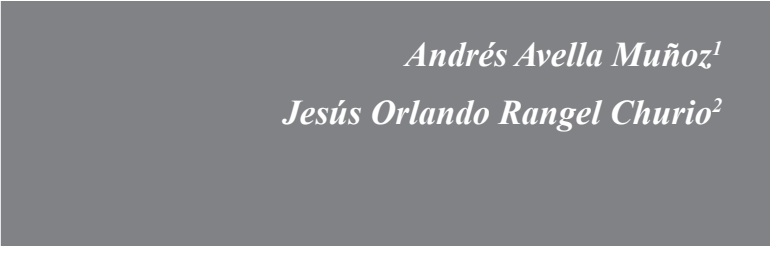

\begin{abstract}
Characterizations of oak forests according to their floristic composition and structure and the identification of the main use requirements of local communities were performed. This permitted recommendations for the sustainable use and preservation of these forest types in the Guantiva-La Rusia-Iguaque conservation corridor (Santander-Boyacá, Colombia). The oak forests correspond to the Quercus humboldtii - Billia rosea major forest formation, which can be categorized into a hierarchical structure of seven forest types. The Q. humboldtii - Ocotea calophylla forests present in the high Andean fringe (>2200-3200 m.a.s.l); the Q. humboldtii - Alchornea grandiflora forests, common in the Andean region include two types of forests, $Q$. humboldtii - Blakea cuatrecasii, and Q. humboldtii - Cyathea multiflora forests; furthermore, these types of forests comprise the Q. humboldtii - Daphnopsis caracasana and $Q$. humboldtii - Pouteria baehniana forests. The final forest type is the Virola macrocarpa - Q. humboldtii forests present in the sub-Andean life zone. According to interviews with members of local communities oak forests are considered the main components
\end{abstract}

of ecosystems of high cultural and social value. The interviews identified two principle uses of oaks, for fuel and for land tenure and property maintenance (fence posts, stakes for crops, timber and tool handles). According to ecological characterization and conservation status assessments the Virola macrocarpa - Q. humboldtii, Q. humboldtii - Pouteria baehniana and Q. humboldtii - Daphnopsis caracasana forests can be used by the community with technical prescriptions. The $Q$. humboldtii - Blakea cuatrecasii and Q. humboldtii - Ocotea calophylla forests should not be used under any circumstance and should be subject to strict strategies for their protection and ecological restoration. The future of oak forests is uncertain unless appropriate strategies based on the generation of co-management agreements with local communities for sustainable use and conservation are proposed and implemented.

\section{RESUMEN}

Los bosques de robles en el corredor GuantivaLa Rusia-Iguaque corresponden a la formación mayor de Quercus humboldtii y Billia rosea, los

1 Instituto de Ciencias Naturales, Universidad Nacional de Colombia. Fundación Natura. eaavella@yahoo.com

2 Instituto de Ciencias Naturales, Universidad Nacional de Colombia. jorangelc@gmail.com 
cuales se clasificaron en una estructura jerárquica de siete tipos: Bosques de Q. humboldtii y Ocotea calophylla (franja altoandina $>3200 \mathrm{~m}$ ), la gran formación de $Q$. humboldtii y Alchornea grandiflora, en la región andina con el robledal de $Q$. humboldtii - Blakea cuatrecasii y el de Q. humboldtii - Cyathea multiflora. En la parte baja de la región andina se diferenciaron los bosques de $Q$. humboldtii y Daphnopsis caracasana y los de $Q$. humboldtii y Pouteria baehniana. Los bosques de Virola macrocarpa y $Q$. humboldtii están presentes en la zona de vida sub-andina. Los robledales son considerados ecosistemas de alto valor cultural y social con dos prácticas principales de uso: como fuente de combustible y en el mantenimiento de las fincas (postes, estacas, madera). Según la caracterización florística y estructural, los bosques de Virola macrocarpa - Q. humboldtii, los de Q. humboldtii - Pouteria baehniana y los de Q. humboldtii - Daphnopsis caracasana podrían ser utilizados por la comunidad, bajo prescripciones técnicas. Los bosques de Q. humboldtii - Blakea cuatrecasii y de $Q$. humboldtii - Ocoteo calophylla no se deben usar, bajo ninguna condición, y deben ser objeto de un programa de protección estricta y restauración ecológica. Se deben implementar estrategias de conservación basadas en la generación de acuerdos de comanejo entre las comunidades locales y las instituciones ambientales que faciliten su conservación bajo esquemas de uso sostenible.

\section{INTRODUCTION}

The presence of oak forests (Quercus humboldtii) in Colombia illustrates the southern boundary of the geographic distribution of this important Holarctic lineage. Its appearance in Colombia is very recent (300 000 years BP) and its ecological dominance is very marked in the three branches of the Andes and isolated massifs in the Caribbean region of the country, between 700 and $3500 \mathrm{~m}$. (Cuatrecasas, 1958; Lozano \& Torres, 1974; Rangel \& Lozano, 1986; Rangel et al., 2005, 2008, 2009; Van der Hammen, 2008; Rangel \& Avella, 2011). In the Andean region of Colombia, currently less than 10 $\%$ of the original forests extent and probably less than $5 \%$ of the high Andean forests remain con- served (Gentry, 1993). However, a more cautious floristic characterization suggests that oak forests have been reduced by $60 \%$ (Rangel 2000; 2005).

Colombian forest legislation in the last century was based on concessions and permissions where the nation supported the exploitation of the forests to the benefit of a few. This degrading situation and the almost extinction of various populations of hardwood tree species motivated the promulgation of a series of prohibitions on forest harvesting by the Instituto Nacional de Recursos Naturales Renovables -INDERENA-, including Resolution 0316 in 1974, by which was prohibited for an indefinite period of time all types of use or harvesting of oak (Quercus humboldtii) in natural stands in the entire country. Subsequently, the oak harvest prohibition was removed in other regions of the country as the Departments of Antioquia, Cauca and Nariño where harvesting was allowed, except for the production of firewood, charcoal or pulp. In the last decade, the Ministry of the Environment, Housing and Territorial Development re-established, through Resolution 0096 in 2006, the indefinite prohibition of oak harvesting throughout the country.

However, in the resolution the sustainable use of the specie is considered as an essential mechanism for its conservation. As a result, local environmental authorities were authorized to carry out technical studies evaluating options for the sustainable use of the species taking into account its wide distribution, the environmental services it provides and its potential for restoration and sustainable use.

Andean oak forests, in addition to their high floristic richness, offer important ecosystem services. The wide distribution of oak in the Colombian Andean region makes it one of the most important species in biological and socio-economic contexts because of its use in restoration programs, management and sustainable use of goods, and in the provision of environmental services (MAVDT, 2006). Subsequent to Resolution 096, several alternative land uses were proposed, including the declaration of protected areas, improvement of forest exploitation processes by local communities, and large projects involving forest harvest. 
Oak forest fragments of considerable extent can be found within the Guantiva-La Rusia-Iguaque "GRI" conservation corridor, located in Santander and Boyacá departments (Solano et al., 2005). Based on the characterization of the floristic composition, aspects of the structure and conservation status, the present study proposes a classification of the oak forests types in the GRI conservation corridor. This oak forest classification along with information related to traditional knowledge and use practices of local communities can be the basis for defining a program of sustainable forest management. We estimate that proposed strategies to conserve oak forests, should take into account not only scientific knowledge but also traditional knowledge, interests and basic needs of local communities.

\section{MATERIAL AND METHODS}

\section{STUDY AREA}

The Guantiva-La Rusia-Iguaque conservation corridor is located on the western slope of the eastern cordillera in the departments of Boyacá and Santander. This corridor is one of the largest areas of well-conserved oak forest remaining in Colombia with an area of approximately 171293 ha (Solano et al., 2005). It influences the hydrological dynamics of the Suarez and Chicamocha river basins that supply potable water to most of the population of Santander and Boyacá, as including cities such as Duitama, San Gil, and Charalá. The present study was carried out in the central area of the conservation corridor encompassing 157000 ha, where approximately 57000 ha of oak forests persist.

The human population of the municipal areas of this study is 192773 inhabitants. Sixty-four percent of the population is located in urban areas and $36 \%$ lives in rural areas (DANE, 2005). Habitat fragmentation is extensive, caused by land tenure dominated by "minifundios" - small landholders (properties of 1-5 ha) and "microfundios" (properties of $<1$ ha). Generally, most of the forested lands are on private property in which land owners are cattle farmers, most of whom have abandoned steeper areas (Solano et al., 2005). The main economic activities in the rural areas are agriculture and livestock. The agricultural sector is characterized by traditional exploitation mainly in slope areas, intensive labor, low crop rotation and dependent on the rainy season (Solano et al. 2005). Nowadays, the land cover in this area includes 36\% natural forest (57000 ha), 22\% mosaics of grassland and agriculture (34200 ha), and $18 \%$ grassland (28500 ha) (Melo, 2008). Along the topographic gradient (1800-3200 m.), there are semi arid, sub humid, and hyper humid climate types. The forests are generally established in rugged terrain with slopes greater that $50 \%$.

An historical analysis of the exploitation processes of the oak forests present in the Guantiva-La RusiaIguaque region, include since the pre-Columbian inhabitants, two indigenous groups, the Chibchas, who were settled in the area now corresponding to the highlands of the Boyacá department, and the Guane group, which was found in some areas of the present Santander department. The region was characterized as an intermediate zone for commercial and cultural exchange between the Guanes and the Chibchas (Raymond, 1997; Solano, 2006). The Chorographic commission (Ancizar, 1853), on its journey to the Charalá region, classified the area as dominated by producers of cotton, corn, turmas potatoes, cassaba, plantains, fruits, and panela. In addition, particularly important in this case, they noted the presence of valuable wood species, especially "cedars" (Cedrela spp.).

Extensive animal husbandry has had an important role in the region. The slim livestock from the eastern Llanos used to be fattened and then sold to other towns in Santander (Solano, 2006). The decrease in agricultural land use might have been a consequence of the large proportion of areas corresponding to subparamo and rugged terrain that do not offer suitable opportunities for agricultural development, and favor the region's isolation (Raymond, 1997). The removal of the oak forests, in the early $20^{\text {th }}$ century, was mainly caused by the occupation of highlands as a result of human migration provoked by political unrest and violence, high rates of poverty, agricultural expansion, re-suitability of properties by the landowners, family heritage dynamics and the construction of roads (Bello, 2006). 
Oak was not considered a valuable species by the local communities in the early $20^{\text {th }}$ century, its demand as a source of wood began during the first half of the century by construction-storage companies in need of levers for the coal mines in Paz del Rio and ties for the national railroad tracks Bello (2006), Solano (2006) and Avella \& Cárdenas (2010) argue that the main uses of the oak forests that shaped their current status were the following: the development of extensive animal husbandry; overexploitation of valuable wood species such as cedar (Cedrela montana), punte o comino (Aniba perutilis) and Colombian pine (Podocarpus oleifolius), mainly commercialized in Tunja, Duitama and Bogota. The oak was required for the fabrication of poles and levers for mining activities as well as the fabrication of charcoal mainly in Paipa, Raquira, and Arcabuco. In addition, there was a strong demand for oak wood for the construction of the railroad tracks by the Colombian Railroad System. It is estimated that for the construction of the rail track from Zipaquira to Chiquinquira (105 $\mathrm{km}), 9252$ tons of charcoal, 665 tons of firewood, 12232 tons of lumber, 3419 tons of round wood and 464 tons of other timber products were used. To cover these needs it was necessary to cut down at least 100000 trees of the most valuable wood present in the region's (Franco, 2007).

\section{METHODOLOGY}

The research comprised two phases: i) the definition of the different types of oak forests, ii) and the opinions of local communities on these forests and their uses of them. The classification of oak forests was made based on a combination of the floristic approach of the classic sigmatist school (BraunBlanquet, 1979), which is followed by botanists and biologists and the structural approach followed by foresters (Cantillo \& Rangel, 2011), which gives more weight to inventories of higher-strata species (trees). We include information from 54 plots with $1000 \mathrm{~m}^{2}$ each one, which were located along an elevation gradient from 1800 to $3200 \mathrm{~m}$.; those individuals with a $\mathrm{DBH} \geq 10 \mathrm{~cm}$ were counted. We followed the method described by Rangel \& Lozano (1986) to differentiate strata, which considers the following height intervals of individuals: $(\mathrm{r})$ : ground $(<0.3 \mathrm{~m})$; (h): herbaceous (0.3-1.49 m); (ar): shrubby (1.5-4.9 $\mathrm{m})$; (A): treelets (5-11.9 m); (Ai): inferior arboreal $(12-25 \mathrm{~m})$ and (As): superior arboreal $(>25 \mathrm{~m})$. In each stratum the number of individuals was counted. These values were used to estimate the relative abundance of each species. Vegetation cover was estimated as a percentage in relation to the surface area or plot. For each individual we calculated the projected area of the canopy over the ground in square meters. The clearances for lack of foliage or branches were not taking in account (Cleef, 1981; Cleef et al., 1984). Estimating species coverage by stratum facilitates estimating the coverage of each species in the forest complex, and also serves to know details of the dynamics of the vegetation with its various states as juveniles, understory individuals and canopy individuals (Cleef et al., 1984; Rangel, 1994). Detailed applications of the procedure in the field are explained in ECOANDES project contributions (Cleef et al., 1984; Rangel et al., 2003; Rangel et al., 2005). The basal area (BA) for each individual was calculated with the $\mathrm{DBH}$ value as follows: $\mathrm{BA}=$ $(\pi / 4) \times\left(\mathrm{DBH}^{2}\right)$. The IPF (Physiognomic Predominance Index) was also calculated (coverage (\%) + density (\%) + dominance (\%)) (Rangel \& Garzón, 1994) as well as the relative IVI (Importance Value Index or Cottam Index, Finol, 1976), which is relative density $(\%)+$ relative dominance $(\%)+$ relative frequency $(\%)$ for the species present in the superior arboreal (As), inferior arboreal (Ai) and treelets (Ar) strata. We used TWINSPAN (McCune \& Mefford, 1997) to detect separation tendencies and define the floristic composition of different forests.

The nomenclature of the different oak forests is based on the dominant species (high values of percent cover, basal area, and relative IVI index). The tables with the floristic composition of the different oak forest include the value of basal area. Voucher specimens under collection number of AAM (Andrés Avella M.), RML (Ruth Medina Lozano) y SPA (Sonia Patricia Angel) were deposited in the Herbario of Distrital University (UDBC). The complete phytosociological treatment will be presented elsewhere. Also, we conducted interviews about the knowledge, conservation, and exploitation practices with some members of local com- 
munities recognized as an expert following the recommendations proposed by Díaz (2008) and Jimenez et al. (2011) about make the interviews with spontaneous questions that emerging in the course of the conversation, facilitating communication and understanding of the topics.

\section{RESULTS}

\section{OAK FOREST TYPES IN THE GUANTIVA- LA RUSIA-IGUAQUE CONSERVATION CORRIDOR}

The oak forests in the area of interest correspond to the Q. humboldii and Billia rosea forest formation, which can be categorized into a hierarchical structure of seven types of forests as shown in figure I.

Major formation dominated by $Q$. humboldii and Billia rosea

Tables I and II

Floristic composition and structure. Dominant species are: Quercus humboldtii, Billia rosea, Compsoneura rigidifolia and Clethra fagifolia. The forests have an average canopy height of $17 \mathrm{~m}$. The superior arboreal stratum (As) is represented by $Q$. humboldtii (5\% of coverage), Virola macrocarpa (1\%), Aniba perutilis (1\%), and Sterigmapetalum tachirense (1\%). In the inferior arboreal stratum (Ai), Quercus humboldtii dominates with $22 \%$, followed by Virola macrocarpa (5\%), Billia rosea (5\%), Compsoneura rigidifolia (1\%), and Clusia $\mathrm{cf}$. bracteosa (1\%). In the treelets'stratum (Ar), Quercus humboldtii was predominant with $8 \%$, followed by Clusia schomburgkiana (3\%), Ladenbergia macrocarpa (2\%), and Clusia cf. bracteosa (2\%). The dominants of the shrubby stratum were Cyathea $\mathrm{cf}$. multiflora with $2 \%$, followed by $Q$. humboldtii (2\%), Palicourea sp. (EHC 366) (1\%), Ladenbergia macrocarpa (1\%), and Clusia discolor (1\%). The species with a greater relative IVI (\%) and IPF (\%) were Q. humboldtii (23$32 \%)$, C. rigidifolia (3-5\%), V. macrocarpa (3-5\%), Clusia schomburgkiana (2-3\%), Clusia cf. bracteosa (2-3\%), and Hyeronima huilensis (2-2\%). A total of 75 individuals (shrubby to arboreal strata), 62 species and 3.7 square meters of basal area (BA) were found by plot of 1000 square meters surface.

Geographic distribution: The vegetation of this major formation includes oaks from the sub Andean and Andean region between 1820 and $3250 \mathrm{~m}$.

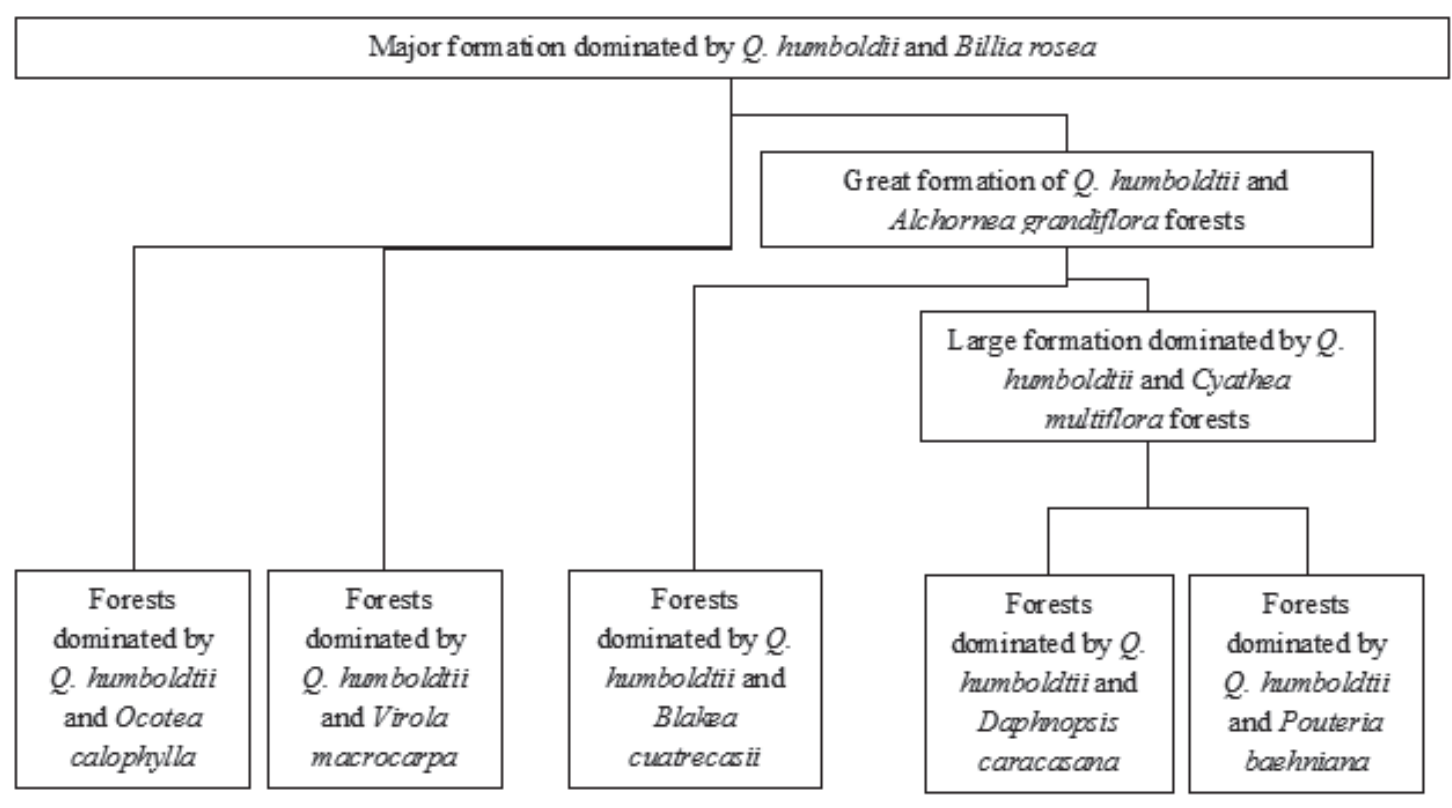

Figure I. Hierarchical structure of different types of oak forests in the Guantiva-La Rusia-Iguaque conservation corridor 
The landscapes include steep ridges, abrupt crests, and moderately steep ridges with slopes between 50 and $75 \%$. There are also flat areas with slopes less than $25 \%$. The parent material derived from clastic sedimentary rocks with interbedded sandyclay-loam structure. The soils are moderately deep.

Conservation status: Human intervention from low to moderate degree because the landscape includes steep ridges, steep ridges and moderately steep ridges. The patches of oak forest growing on flat areas show a high degree of human intervention, which means low degree of conservation.

Forests dominated by $Q$. humboldtii and Ocotea calophylla

\section{Table I}

Floristic composition and structure: Dominant species are: Q. humboldtii, Clusia multiflora, Weinmannia tomentosa, and Ocotea calophylla. The inferior arboreal stratum (Ai) is represented by Quercus humboldtii with $69 \%$, followed by $O$. calophylla (3\%), Centronia brachycera (3\%), and Miconia sp. (AAM 983) (3\%). In the treelets'stratum (Ar), $Q$. humboldtii was predominant with $21 \%$, followed by C. multiflora (3\%), W. tomentosa (3\%), Schefflera velutina (2\%) and Oreopanax bogotensis (2\%). The dominants of the shrubby stratum were $Q$. humboldtii with $2 \%$, followed by Cyathea cf. multiflora (1\%), and Miconia ligustrina (1\%). The species with a greater relative IVI (\%) and IPF (\%) were Q. humboldtii (48-70\%), O. calophylla (4-4\%), C. multiflora (3-3\%) and $W$. tomentosa (3-4\%). A total of 83 individuals (shrubby to arboreal strata), 12 species and 4.6 square meters of basal area (BA) were found by plot of 1000 square meters surface.

Geographic distribution: These oak forests grow on the Andean region between 2316 and 3250 m., especially in the high Andean fringe. The landscapes include steep ridges, abrupt crests, and moderately steep ridges with slopes between 50 and $75 \%$.

Conservation status: Due to its localization in the top of mountains (high Andean fringe), these patches of oak forest shows a low degree of human intervention which means a good status of conservation.

Forests dominated by Q. humboldtii and Virola macrocarpa

Table I

Floristic composition and structure: Dominant species are: Q. humboldtii, Billia rosea, Vismia cf. baccifera, Elaeagia mariae, S. tachirense and V. macrocarpa. The superior arboreal stratum (As) with low coverage is represented by $Q$. humboldtii (2\%), V. macrocarpa (1\%), Aniba perutilis (1\%) and $S$. tachirense (1\%). In the inferior arboreal stratum (Ai), V. macrocarpa dominates with $9 \%$, followed by $Q$. humboldtii (6\%), Compsoneura rigidifolia (4\%), Eschweilera sessilis (2\%), B. rosea (2\%), Faramea flavicans (2\%) and S. tachirense $(2 \%)$. In the treelets'stratum (Ar), C. rigidifolia dominates with $5 \%, V$. macrocarpa (2\%), C.lusia schomburgkiana (2\%), F. flavicans (2\%), and $S$. tachirense (1\%). The dominants of the shrubby stratum were Micropholis crotonoides with 3\%, followed by Alchornea grandiflora (2\%), and Myrsine pellucida (1\%). The species with a greater relative IVI (\%) and IPF (\%) were Q. humboldtii (6-8\%), V. macrocarpa (11-14\%), C. rigidifolia (11-9\%), S. tachirense (3-4\%), F. flavicans (4-4\%), and B. rosea (3-3\%). A total of 94 individuals (shrubby to arboreal strata), 33 species and 3.2 square meters of basal area (BA) were found by plot of 1000 square meters surface.

Geographic distribution: These oak forests grow on sub Andean region between 1850 and $1950 \mathrm{~m}$. The landscapes include steep ridges and abrupt crests with slopes between 12 and 50\%.

Conservation status: These oak forests shows a low degree of human intervention which means a good status of conservation due to the fact that they are inside a Protected Area called Estación Biológica Cachalú. However, in the regional landscape, these oak forests had been the most affected by the coffee plantations. There are only reduced tracts of these forests in good conservation status. 
Oak forests types of Quercus humboldtii in the guantiva-la rusia-iguaque corridor (Santander-Boyacá, Colombia)

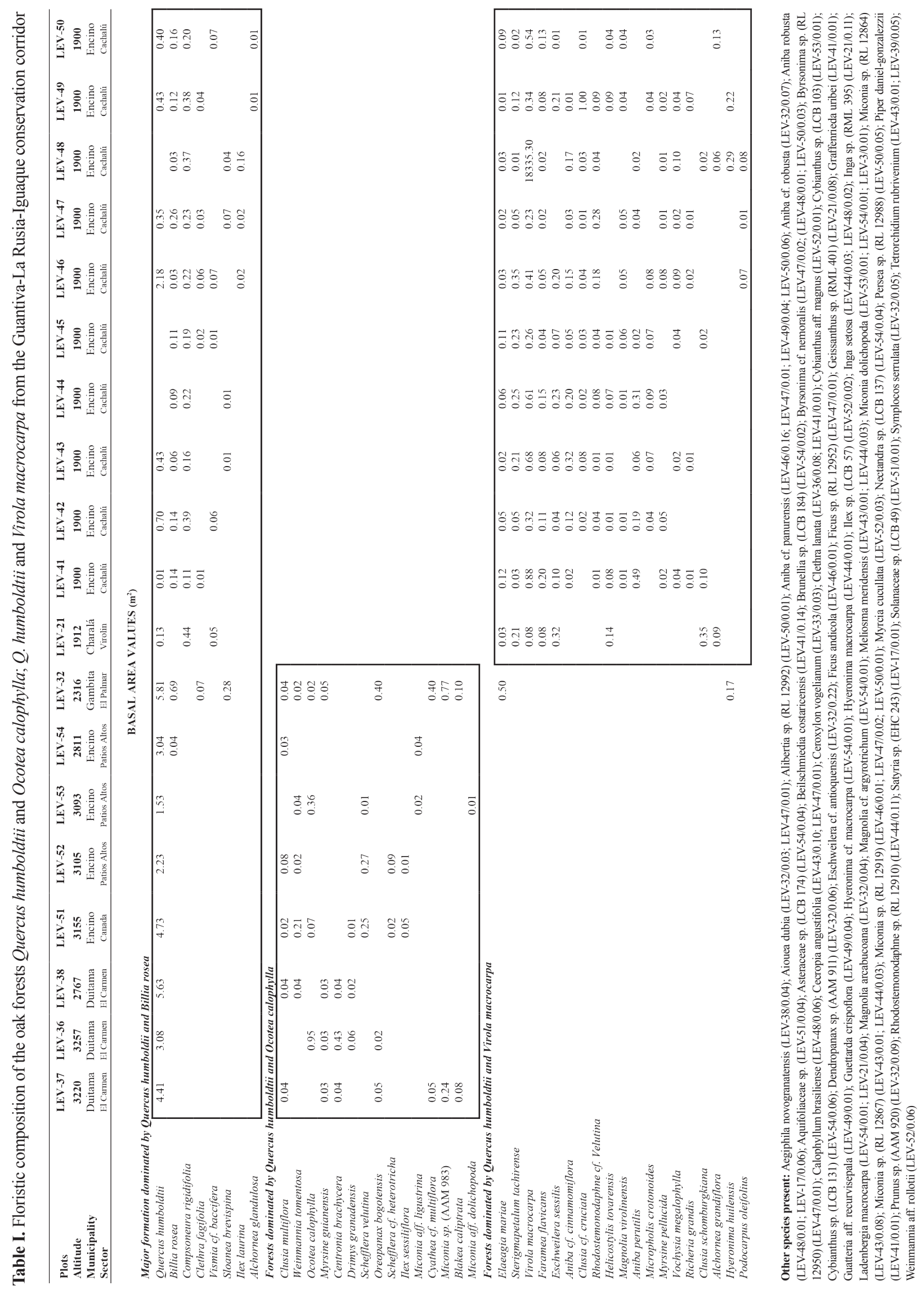




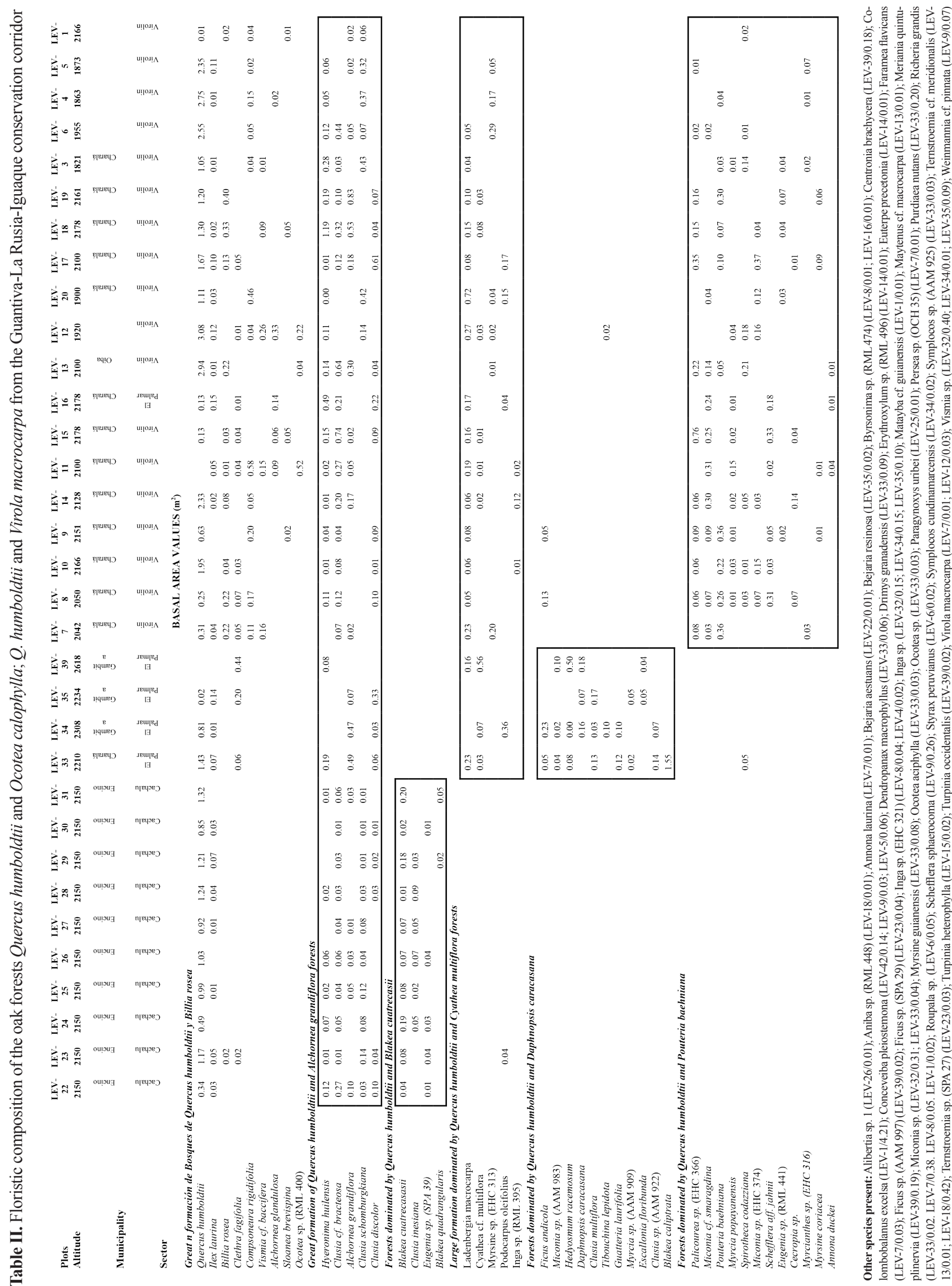


Oak forests types of Quercus humboldtii in the guantiva-la rusia-iguaque corridor (Santander-Boyacá, Colombia)

Great formation of $Q$. humboldtii and Alchornea grandiflora forests

Table II

Floristic composition and structure: Dominant species are: Q. humboldtii, Ilex laurina, Hyeronima huilensis, Clusia cf. bracteosa, and Alchornea grandiflora. The superior arboreal stratum (As) with low coverage is represented by $Q$. humboldtii (3\%), H. huilensis (2\%), and Clusia cf. bracteo$s a(1 \%)$. In the inferior arboreal stratum (Ai), $Q$. humboldtii dominates with $16 \%$, followed by Clusia cf. bracteosa (4\%), Billia rosea (2\%), A. grandiflora (2\%), and Clusia schomburgkiana (2\%). In the treelets'stratum (Ar), Q. humboldtii dominates with $8 \%, C$. schomburgkiana (4\%), Clusia cf. bracteosa (3\%), and Ladenbergia macrocarpa (3\%). The dominants of the shrubby stratum were Cyathea cf. multiflora with 3\%, followed by $Q$. humboldtii (2\%), Eugenia sp. (SPA 39) (2\%), and Ladenbergia macrocarpa (2\%). The species with a greater relative IVI ( $\%)$ and IPF (\%) were Q. humboldtii (20-27\%), Clusia cf. bracteosa (4-5\%), H. huilensis (4-4\%), C. schomburgkiana (4-4\%), L. macrocarpa (4-4\%), and $A$. grandiflora (4-4\%). A total of 68 individuals (shrubby to arboreal strata), 17 species and 3.2 square meters of basal area (BA) were found by plot of 1000 square meters surface.

Geographic distribution: These oak forests grow on the sub Andean and Andean region between 1 820 and $2600 \mathrm{~m}$. The landscapes include steep ridges, and moderately steep ridges with slopes between 50 and $75 \%$. The soils are moderately deep.

Conservation status: These oak forests types show medium to high degree of human intervention which means an intermediate status of conservation. Generally speaking, this region is where the local communities use in a more intensive way the oak forests. The degradation of arboreal and treelets strata is high and in the regional landscape, the patches of this type of forests are fragmented and scarcely connected, therefore only a few of these forests are in good conservation status.

Forests dominated by $Q$. humboldtii and Blakea cuatrecasii
Table II

Floristic composition and structure: Dominant species are: Q. humboldtii, Blakea cuatrecasii, and Clusia inesiana. The inferior arboreal stratum (Ai) is represented by $Q$. humboldtii dominates with $7 \%$, followed by Clusia cf. bracteosa (1\%), C. inesiana (1\%) and Hyeronima huilensis (1\%). In the treelets'stratum (Ar), Q. humboldtii dominates with $13 \%, B$. cuatrecasasii (3\%), C. inesiana (2\%), and Eugenia sp. (SPA 39) (2\%). The dominants of the shrubby stratum were Blakea quadrangularis with 3\%, followed by $Q$. humboldtii (2\%), and Alchornea grandiflora (1\%). The species with a greater relative IVI $(\%)$ and IPF $(\%)$ were Q. humboldtii (42-59\%), B. cuatrecasii (9-8\%), Clusia schomburgkiana (7-6\%), and $C$. inesiana (7-6\%). A total of 41 individuals (shrubby to arboreal strata), 10 species and 1.4 square meters of basal area (BA) were found by plot of 1000 square meters surface.

Geographic distribution: These oak forests grow on the sub-Andean region at $2000 \mathrm{~m}$. The landscapes include steep ridges, and moderately steep ridges with slopes between 50 and $75 \%$.

Conservation status: There are important remnants of these oak forests in the region, but they had been affected by selective logging and a process of degradation and deforestation. The oak forests included inside the Protected Area called Estación Biológica Cachalú show a low degree of human intervention which means a good status of conservation

Large formation dominated by $Q$. humboldtii and Cyathea multiflora forests

Table II

Floristic composition and structure: Dominant species are: Q. humboldtii, Ilex laurina, Billia rosea, Hyeronima huilensis, Ladenbergia macrocarpa, and Cyathea cf. multiflora. The superior arboreal stratum (As) with low coverage is represented by $Q$. humboldtii (3\%), B. rosea (1\%), H. huilensis (1\%), and Podocarpus oleifolius (1\%). In the inferior 
arboreal stratum (Ai), Q. humboldtii dominates with $21 \%$, followed by Clusia $\mathrm{cf}$. bracteosa (3\%), B. rosea (2\%), Alchornea grandiflora (2\%), and L. macrocarpa (2\%). In the treelets'stratum (Ar), Q. humboldtii dominates with 5\%, L. macrocarpa (4\%), Clusia discolor (4\%), and Cyathea cf. multiflora (3\%). The dominants of the shrubby stratum were Cyathea cf. multiflora with $3 \%$, followed by $Q$. humboldtii (2\%), L. macrocarpa $(2 \%)$, and $C$. discolor (1\%). The species with a greater relative IVI $(\%)$ and IPF $(\%)$ were $Q$. humboldtii (16-22\%), L. macrocarpa (4-5\%), C. discolor (4-5\%), Clusia cf. bracteosa (4-5\%), H. huilensis (4-5\%), A. grandiflora (4-3\%). A total of 79 individuals (shrubby to arboreal strata), 20 species and 3.96 square meters of basal area (BA) were found by plot of 1000 square meters surface.

Geographic distribution: These oak forests grow on the sub-Andean region between 1820 and 2200 $\mathrm{m}$. But plot (LEV-39) was located at $2300 \mathrm{~m}$. The landscapes include moderately steep ridges with slopes between 50 and $75 \%$. The soils are moderately deep.

Conservation status: There are important tracts of these oak forests still, but these forests had been affected by selective logging, process of degradation and deforestation, because the local communities use the oak forests in more intensive way. The human intervention shows a medium degree, which means an intermediate status of conservation.

Forests dominated by $Q$. humboldtii and Daphnopsis caracasana

Table II

Floristic composition and structure: Dominant species are: Q. humboldtii, Billia rosea, Alchornea grandiflora, Daphnopsis caracasana, and Clusia multiflora. The inferior arboreal stratum (Ai) is represented by $Q$. humboldtii dominates with $12 \%$, followed by $D$. caracasana (4\%), Clethra fagifolia (4\%) and C. multiflora (4\%). In the treelets'stratum (Ar), Ladenbergia macrocarpa dominates with $5 \%$, Ilex laurina (4\%), C. fagifolia (3\%), and Escallonia cf. floribunda (3\%). The dominants of the shrubby stratum were Cyathea $c f$. multiflora with $5 \%$, followed by Clusia discolor (2\%), C. fagifolia (2\%), D. caracasana (1\%), and Tibouchina lepidota (1\%). The species with a greater relative IVI (\%) and IPF (\%) were $Q$. humboldtii (8-10\%), C. fagifolia (8-9\%), Cyathea cf. multiflora (7-8\%), Clusia discolor (5-5\%), A. grandiflora (5-5\%), and C. multiflora (4-4\%). A total of 75 individuals (shrubby to arboreal strata), 18 species and 4.1 square meters of basal area (BA) were found by plot of 1000 square meters surface.

Geographic distribution: These oak forests grow on the Andean region between 2210 and $2600 \mathrm{~m}$. The landscapes include moderately steep ridges and abrupt crests with slopes between 50 and $75 \%$. The soils are moderately deep.

Conservation status: The local communities used intensively these oak forests in the past century. There are important tracts of these oak forests with evidence of selective logging and process of degradation and deforestation. Human intervention shows medium to high degree which means an intermediate status of conservation.

Forests dominated by $Q$. humboldtii and Pouteria baehniana

Table II

Floristic composition and structure: Dominant species are: Q. humboldtii, Ilex laurina, Pouteria baehniana, Spirotheca codazziana, and Ladenbergia macrocarpa. The superior arboreal stratum (As) with low coverage is represented by $Q$. humboldtii (2\%), Billia rosea (1\%), and P. baehniana (1\%). In the inferior arboreal stratum (Ai), Q. humboldtii dominates with $22 \%$, followed by Clusia cf. bracteosa (3\%), Billia rosea (2\%), Hyeronima huilensis (2\%), and Alchornea grandiflora (2\%). In the treelets'stratum (Ar), Q. humboldtii dominates with $6 \%$, Clusia schomburgkiana (5\%), Clusia cf. bracteosa (4\%), Palicourea sp. (EHC 366) (4\%), L. macrocarpa (4\%), and Miconia cf. 
smaragdina $(4 \%)$. The dominants of the shrubby stratum were Palicourea sp. (EHC 366) with $3 \%$, followed by $Q$. humboldtii (1\%), L. macrocarpa (1\%), Schefflera aff. jahnii (1\%), and Myrcia popayanensis $(2 \%)$. The species with a greater relative IVI (\%) and IPF (\%) were Q. humboldtii (18$24 \%)$, Clusia cf. bracteosa (5-6\%), L. macrocarpa (4-5\%), Palicourea sp. (EHC 366) (4-5\%), H. huilensis (4-4\%), and A. grandiflora (4-4\%). A total of 80 individuals (shrubby to arboreal strata), 20 species and 3.9 square meters of basal area (BA) were found by plot of 1000 square meters surface.

Geographic distribution: These oak forests grow on the sub-Andean region between 1820 and $180 \mathrm{~m}$. The landscapes include moderately steep ridges with slopes between 50 and $75 \%$. The soils are moderately deep.

Conservation status: These oak forests had been the most affected by the coffee plantations, and currently there are reduced in good conservation status. Human intervention shows medium degree which means an intermediate status of conservation.

\section{KNOWLEDGE OF OAK FORESTS BY LOCAL COMMUNITIES: CONSERVATION AND EXPLOITATION PRACTICES}

The demand for wood resources derived from oak forests began in the first half of the $20^{\text {th }}$ century, supported by a series of regulations that permitted the indiscriminate exploitation of forests. The main activities that shaped the current state of the oak forests were: i) the construction of railroad tracks, ii) the manufacture of poles and levers for mining, iii) the selective extraction of valuable wood species such as cedro, comino and pino colombiano (species classified within the genera Cedrela, Ocotea, Aniba and Podocarpus) for trade, iv) handmade charcoal, and v) the expansion of livestock activities which accelerated deforestation.

According to interviews with members of local communities, oak forests are considered ecosystems of high cultural and social value. Their direct use values is linked to the domestic supply of firewood and wood (for fences and other products) required by the family unit. A single family in a rural area uses 5 to $8 \mathrm{tn} /$ year (ca. $10 \mathrm{~m}^{3} /$ year) of wood for fuelwood and 5 to $8 \mathrm{~m}^{3}$ of wood for fences and land maintenance (Aristizabal, 2010; Avella \& Cardenas, 2010). Most of this wood is obtained from native species including not only $Q$. humboldtii but also aliso (Alnus acuminata), amarillo (Nectandra spp., Ocotea calophylla), patavaca (Clethra fimbriata), encenillos (Weinmannia pubescens, W. tomentosa), cucharos (Myrsine guianensis), gaques (Clusia multiflora, C. schomburgkiana), tunos (Miconia sp. Blakea cuatrecasii, Centronia sp.), canelo (Aniba robusta, Aniba perutilis), and, in some cases, introduced species of genera such as Acacia, Eucaliptus and Pinus.

Nonetheless, not only the direct use values are relevant. The protection of watersheds and wildlife fauna as well as the prevention of soil erosion are among the oak forest's indirect use values recognized by the communities. In terms of passive use values, oak trees and oak woods have been linked to the local families' histories for a long time and are the main symbols characterizing the region.

The interviews identified two principle use practices of oaks, for fuel and for land tenure and property maintenance (fence posts, stakes for crops, timber and tool handles). Currently, the substitution of wood products by more expensive hydrocarbon fuels, plastic and metallic fences and other supplies for maintenance is not a financially feasible option in an area where resources to fulfill basic needs are already limited. Consequently, most community members believe that the regulated domestic use of forest stands should be allowed and be accompanied by educational programs and training, and the provision of economic benefits to cover the transition towards the use of alternative fuel options. These programs are deemed necessary for the sustainability of oak forestry.

Local communities have also noticed the loss of biodiversity in oak forests. Due to this, initiatives that seek the restoration and recovery of the original condition of the oak forests will be supported by them. According to Avella \& Cárdenas (2010), at this point one has to take into account the knowled- 
ge of the local peoples on the methods of propagation, and the establishment, management and harvesting of some species of native forests like harvesting of only over-mature trees, developing of natural regeneration management techniques, and identification and selection of potential species for timber and non-timber products. This life experience could be the appropriated reference for the design of alternative models of conservation and sustainable use of oak forests. Among the alternative actions that suggest local communities with regard to the management and conservation of oak forests, we can cite:

- Conduct forest zoning with the participation of local communities.

- Develop and implement forest management plans to optimize the regulation, planning and exploitation process.

- Conduct pilot studies to define optimal procedures to prevent, regulate, mitigate and compensate for the negative impacts of the exploitation of oak forests in selected areas for sustainable use.

- Strengthening the technical capacity of local communities and institutions to improve the domestic harvesting practices.

- Propose shared management agreements with local communities for conservation and sustainable use of oak forests.

- Promote the allocation of financial incentives referred to in the environmental legislation of the country for local communities in recognition of their efforts to preserve oak forests.

- Develop technology packages for the efficient use of firewood.

- Promotion and implementation of agroforestry and silvopastoral systems to protect soils and water sources.

\section{DISCUSSION}

The structural parameter values for number of individuals, number of arboreal species and basal area (Table III) can serve as proxies for conservation status and the possibility of sustainable management for various types of oak forests. To compare among the different parameters, the average values for each were calculated. The results reveal low values for upper tree layer coverage $(>25 \mathrm{~m})$, which indicates that most of the oak forests have been intervened to extract the valuable species. The parameter comparison also indicates that forests as $Q$. humboldtii - V. macrocarpa and $Q$. humboldtii - Pouteria baehniana, with individuals that are equal to or greater than $20 \mathrm{~m}$ in height and that have greater numbers of individuals and species than average ( $X=75$ individuals and $X=19$ species) can be used by farmers employing sustainable silvicultural practices. Sustainable management practices allow some level of use by local communities but also ensure the protection of these forests that were affected by conversion to coffee plantations. This approach will also help the recovery of endangered species that were affected by selective logging such as Aniba perutilis, Cedrela montana and Podocarpus oleifolius.

Q. humboldtii - Daphnopsis caracasana forests have high basal areas, numbers of individuals and numbers of species. Despite the intensive use to which these forests were subjected in the last century, their current extension and conservation status are valid arguments for incorporation into programs for sustainable forest management. $Q$. humboldtii - Ocotea calophylla forests, localized in the High-Andean fringe, are noteworthy for their floristic homogeneity and high basal area values. However, this forest type is more important for its ability to regulate hydrological cycles, especially considering that nowadays, there is a clear tendency among forest managers to favor the establishment of rigorous protection policies to preserve water resources. For these reasons, we do not suggest developing forest management programs in these oak forest type. Q. humboldtii - Blakea cuatrecasii forests should not be subject to any 
use, because they have very low numbers of individuals, species and basal area.

Currently, approximately 57000 ha (30\%) of the original 180000 ha of oak forests still exist in the central area of the conservation corridor. The majority of the forests are on private property, following a strong tendency toward land fragmentation caused by a significant "small landholders" tradition. The oak forests are highly important socially and culturally for the farming communities of the region. The use of these forests is directly related to the need for firewood and wood for domestic uses. Average wood consumption per family is between approximately 15 and $20 \mathrm{~m}^{3}$ by year (Avella \& Cardenas, 2010), an amount that is mostly provided by native species associated with oak forests. However, despite the importance of these forests for local communities and institutions, their degradation and deforestation continue. These valuable ecosystems (from a biological perspective) are primarily associated with farming communities, which cover $87 \%$ of the territory where oak forests are present. These communities have a strong relationship with the forests, use some of their ecosystem services and follow a series of practices for their use and harvesting. Natural forests of good quality can also offer important environmental services such as carbon storage and the preservation of fauna and flora. These functions can only be preserved through the application of rational management practices such as management of seed trees, establishment of a minimum diameter of cutting, structural retention at the stand level, natural regeneration management, the maintenance of connectivity at the landscape level, the use of knowledge of natural disturbance regimes to guide forest management practices, and techniques to reduce the impact of logging. Implementing these practices could help to maintain the potential of forest resources to produce a complete series of benefits for local communities.

Local knowledge about management and preservation of oak forests has been generated in the region (Avella \& Cardenas, 2010), and includes practices such as harvesting of only over-mature trees, development of natural regeneration management techniques, development of management protocols in native species nurseries, and identification and selection of potential species for timber and nontimber products. Considering the slow development of scientific and technical knowledge about oak forest management, the traditional knowledge of local communities could provide important contributions to the design of management alternatives that could effectively contribute to the preservation and sustainable use of the oak forests present in the region.

\section{CONCLUSIONS}

In a continuous altitudinal gradient the oak forests of the Guantiva - La Rusia - Iguaque corridor grow from the sub-Andean region 1900 to $3200 \mathrm{~m}$ near the lower limits of the Páramo region, and can be categorized into a hierarchical structure of seven types of forests: Q. humboldtii - Ocotea calophylla forests, present in the high Andean region (>2200-3200 m); the great formation of $Q$. humboldtii - Alchornea grandiflora forests, common in the Andean region and which includes the Q. humboldtii - Blakea cuatrecasii and Q. humboldtii - Cyathea multiflora forest types; and the Q. humboldtii - Daphnopsis caracasana and the Q. humboldtii - Pouteria baehniana forests. Virola macrocarpa - Q. humboldtii forests are present in the sub-Andean life zone.

According to our results on floristic and physiognomic characterization, forests with high values in basal area, number of individuals, number of species and average canopy height, such as Virola macrocarpa - Q. humboldtii, Q. humboldtii - Pouteria baehniana, and Q. humboldtii - Daphnopsis caracasana forests, can be used by the community with technical prescriptions for management of seed trees, establishment of a minimum diameter of cutting, harvesting of over-mature trees, structural retention at the stand level, techniques to reduce logging impacts, natural regeneration management and the maintenance of connectivity at the landscape level, all of which could allow their perpetuation. Oak forests with low richness and basal area values such as $Q$. humboldtii - Blakea cuatrecasii forests and forests that provide important hydrological regulation services such as Q. humboldtii - Ocoteo calophylla should not be 
Table III. Floristic and structural aspects of the oak forests in the central area of the GRI conservation corridor

\begin{tabular}{|c|c|c|c|c|c|c|c|c|}
\hline $\begin{array}{l}\text { Plant } \\
\text { formations }\end{array}$ & $\begin{array}{c}\text { Strata } \\
\text { coverage } \\
\text { (highest) }\end{array}$ & $\begin{array}{l}\text { Height } \\
\text { average } \\
\text { canopy } \\
\text { (m) }\end{array}$ & $\begin{array}{c}\text { Height } \\
\text { Max. } \\
\text { (m) }\end{array}$ & $\begin{array}{l}\text { No. of } \\
\text { Ind. } \\
X=75\end{array}$ & $\begin{array}{l}\begin{array}{l}\text { No. tree } \\
\text { species }\end{array} \\
X=19\end{array}$ & $\begin{array}{c}\text { Basal } \\
\text { area } \\
\left(\mathbf{m}^{2}\right) \\
\mathbf{X}=\mathbf{3 . 4}\end{array}$ & $\begin{array}{l}\text { Dominant species } \\
\text { According to } \\
\text { relative IVI (\%) } \\
\text { and IPF (\%) }\end{array}$ & Natural region \\
\hline $\begin{array}{l}\text { Q. humboldtii } \\
\text { and Ocotea } \\
\text { calophylla } \\
\text { forests }\end{array}$ & $\begin{array}{c}\text { Ai } 86 \% \text {. Ar } \\
38 \%\end{array}$ & 17 & 24 & 83 & 12 & 4.6 & $\begin{array}{l}\text { Q. humboldtii } \\
(48 ; 70), \text { Ocotea } \\
\text { calophylla }(4 ; 3), \\
\text { Clusia multiflora }(3 ; \\
\text { 3), and Weinmannia } \\
\text { tomentosa }(3 ; 4) \text {. }\end{array}$ & $\begin{array}{l}\text { High-Andean fringe } \\
(80 \%) \text { and Andean } \\
(20 \%) \\
\text { Altitudinal limit: } \\
2316-3250 \mathrm{~m}\end{array}$ \\
\hline $\begin{array}{l}\text { Q. humboldtii } \\
\text { and Virola } \\
\text { macrocarpa } \\
\text { forests }\end{array}$ & $\begin{array}{c}\text { Ai } 52 \%, \mathrm{Ar} \\
27 \%\end{array}$ & 20 & 30 & 94 & 33 & 3.2 & $\begin{array}{l}\text { Q. humboldtii } \\
(6 ; 8), \text { Virola } \\
\text { macrocarpa }(11 ; \\
\text { 14), Compsoneura } \\
\text { rigidifolia }(11 ; 9), \\
\text { Sterigmapetalum } \\
\text { tachirense }(3 ; 4), \\
\text { Faramea flavicans } \\
(4 ; 4), \text { and Billia } \\
\text { rosea }(3 ; 3) .\end{array}$ & $\begin{array}{l}\text { Sub-Andean } \\
\text { Altitudinal limit: } \\
1850 \text { - } 1950\end{array}$ \\
\hline $\begin{array}{l}\text { Q. humboldtii } \\
\text { and Blakea } \\
\text { cuatrecasii } \\
\text { forests. }\end{array}$ & $\begin{array}{c}\text { Ai } 24 \%, \mathrm{Ar} \\
10 \%\end{array}$ & 13 & 20 & 41 & 10 & 1.4 & $\begin{array}{l}\text { Q. humboldtii } \\
(42 ; 59), \text { Blakea } \\
\text { cuatrecasii } \\
(9 ; 8), \text { Clusia } \\
\text { schomburgkiana } \\
(7 ; 6), \text { and Clusia } \\
\text { inesiana }(7 ; 6) .\end{array}$ & $\begin{array}{l}\text { Sub-Andean } \\
2000 \mathrm{~m}\end{array}$ \\
\hline $\begin{array}{l}\text { Q. humboldtii } \\
\text { and } \\
\text { Daphnopsis } \\
\text { caracasana } \\
\text { forests }\end{array}$ & $\begin{array}{c}\mathrm{Ai} 48 \%, \mathrm{Ar} \\
50 \%\end{array}$ & 13 & 20 & 75 & 18 & 4.1 & $\begin{array}{l}\text { Q. humboldtii (8; } \\
\text { 10), Clethra fagifolia } \\
(8 ; 9), \text { Cyathea } \mathrm{cf} \text {. } \\
\text { multiflora }(7 ; 8), \\
\text { Clusia discolor } \\
(5 ; 5), \text { Alchornea } \\
\text { grandiflora }(5 ; 5) \text {, } \\
\text { and Clusia multiflora } \\
(4 ; 4) .\end{array}$ & $\begin{array}{l}\text { Andean } \\
\text { Altitudinal limit: } \\
2210 \text { - } 2600\end{array}$ \\
\hline $\begin{array}{l}\text { Q. humboldtii } \\
\text { and Pouteria } \\
\text { baehniana } \\
\text { forests }\end{array}$ & $\begin{array}{c}\text { Ai } 57 \%, \mathrm{Ar} \\
60 \%\end{array}$ & 17 & 30 & 80 & 20 & 3.9 & $\begin{array}{l}\text { Quercus humboldtii } \\
(18 ; 24), \text { Clusia } \\
\text { cf. bracteosa }(5 ; \\
6), \text { Ladenbergia } \\
\text { macrocarpa }(4 ; 5), \\
\text { Hyeronima huilensis } \\
(4 ; 4), \text { and Alchornea } \\
\text { grandiflora }(4 ; 4) .\end{array}$ & $\begin{array}{l}\text { Andean (70\%) } \\
\text { Sub-Andean (30\%) } \\
\text { Altitudinal } \\
\text { limit:1800 - } 2180\end{array}$ \\
\hline
\end{tabular}


used under any circumstance and should be subject to strict strategies for the protection, restoration and recovery of their biodiversity and ecosystem services.

Due to the cultural and social values that oak forests represent to local communities, and the knowledge and interest in forest management expressed by the communities themselves, it is attractive to consider a strategy of allowing controlled use to satisfy minimum demands for firewood and domestic uses based on models of sustainable development. Therefore, it is necessary to design integral conservation strategies that contemplate not only protection and restoration of biological diversity, maintenance of ecological integrity and protection of soil and water, but also actions that promote to the sustainability of the supply of timber and non-timber products as an essential component. Doing so will consolidate the processes of biodiversity conservationas well as improvethe quality of life for the local communities.

The conservation strategy described here should be based on the generation of co-management agreements with local communities, and should receive the strong support of governmental entities, universities, research institutions and local NGOs. This coalition of actors could favor the integral conservation of the oak forests and the improvement of the quality of life of local communities. Various dimensions are recognized in oak forest ecosystems, including the provisioning of natural resources, linkages with adjacent ecosystems, ecosystem services, protection of biodiversity, social and cultural value and natural heritage. Such perspectives provide technical and methodological elements to the new forest management approach that must be implemented in Colombian oak forests following the recommendations of the Ecosystem Approach (Rangel et al., 2002; SCDB, 2004).

\section{ACKNOWLEDGEMENTS}

We thank the Conservation and Sustainable Development Program of the John D. and Catherine T. MacArthur Foundation. To the National University of Colombia, the Neotropical Foundation and the Natura Foundation for the support of the research project "Evaluación de la dinámica del carbono en los bosques de roble (Fagáceas) de la Cordillera Oriental de Colombia". Also we thank to Bruce Young and Carmen Josse, for their kind cooperation in the translation of the manuscript.

\section{BIBLIOGRAPHICAL REFERENCES}

Ancízar, M. (1853). Peregrinación de Alpha por las provincias del norte de la Nueva Granada en 1850 y 1851. Bogotá: Echeverría Hermanos.

Aristizábal, J. (2010). Estufas mejoradas y bancos de leña: una alternativa de autoabastecimiento energético a nivel de finca para comunidades dependientes de los bosques de roble de la cordillera oriental. Colombia Forestal, 13 (2), 245-256.

Avella, A., \& Cárdenas, L. (2010). Conservación y uso sostenible de los bosques de roble. Estudio de caso en el Corredor de Conservación Guantiva-La Rusia-Iguaque, departamentos de Santander y Boyacá, Colombia. Colombia Forestal, 13 (1), 5-30.

Bello, R. (2006). Expresiones culturales alrededor del roble en el corredor Guantiva-La Rusia-Iguaque. En C. Solano, \& N. Vargas (eds.). Memorias del I Simposio Internacional de Robles y Ecosistemas Asociados (pp. 225-234). Bogotá: Fundación Natura-Pontificia Universidad Javeriana.

Braun-Blanquet, J. (1979). Fitosociología: Bases para el estudio de las comunidades vegetales. Madrid: Ediciones H. Blume.

Cantillo, E., \& Rangel, J.O. (2011). La Estructura y el patrón de la riqueza de la vegetación del Parque Nacional Natural Los Nevados. En J.O. Rangel (ed.). Colombia diversidad biótica XI. Patrones de la estructura y de la riqueza de la vegetación en Colombia (pp. 69-125). Bogotá D.C: Universidad Nacional de Colombia-Instituto de Ciencias Naturales.

Cleef, A.M., Rangel, J.O., \& Van der Hammen, T. (1984). La vegetación de las selvas del Tran- 
secto Buritaca. En T. Van der Hammen, \& P. Ruiz (eds.). Estudios de ecosistemas Tropandinos-Ecoandes 2. La Sierra Nevada de Santa Marta Colombia Transecto Buritaca-La Cumbre (pp. 695-798). Berlín-Stuttgaart: J. Cramer.

Cuatrecasas, J. (1958). Aspectos de la vegetación natural de Colombia. Revista Academía Colombiana de Ciencias Exactas, Físicas y Naturales 10 (40), 221-268.

Departamento Administrativo Nacional de Estadística-DANE- (2005). Censo General 2005 - Información Básica. República de Colombia.

Díaz, M. (2008). Evaluación del uso actual de especies forestales asociadas a bosque de roble en las veredas Patios Altos, Patios Bajos y Canadá, Municipio de Encino-Santander (Trabajo de grado, Biología). Tunja: Escuela de Ciencias Biológicas, Facultad de Ciencias Básicas, Universidad Pedagógica y Tecnológica de Colombia.

Escobar, V. (2009). Procesos de organización social para la conservación del bosque de robles y sus ecosistemas asociados en Paipa y Duitama en el período comprendido entre 2004 a 2008 (Trabajo de grado, Trabajo Social). Bogotá: Universidad Externado de Colombia, Facultad de Ciencias Sociales y Humanas.

Finol, H. (1976). Métodos de regeneración natural de algunos tipos de bosques venezolanos. Revista Forestal Venezolana, 26, 17-44.

Franco, R. (2007). Elementos para una historia ambiental de la región de la laguna de Fúquene en Cundinamarca y Boyacá. En L. Franco, \& G.I. Andrade (eds.). Fúquene, Cucunuba y Palacio, Conservación de la biodiversidad y manejo sostenible de un ecosistema lagunar andino (pp. 61-102). Bogotá: Fundación Humedales, Instituto de Investigaciones Alexander von Humboldt.

Gentry, A. (1993). Vistazo general a los ecosistemas nublados andinos y la flora de Carpanta.
En G.I. Andrade (ed.). Carpanta: Selva nublada y páramo (pp. 67-80). Santafé de Bogotá: Fundación Natura Colombia, Edit. Presencia.

Jiménez-E., N.D., Albuquerque, U. \& Rangel, J.O. (2011). Huertos familiares en la Bahía de Cispatá, Córdoba, Colombia. Bonplandia, 20 (2), 309-328.

Lozano, G., \& Torres, J.H. (1974). Aspectos generales sobre la distribución, sistemática fitosociológica y clasificación ecológica de los bosques de robles (Quercus) en Colombia. Ecología Tropical, 1 (2), 45-79.

McCune, B., \& Mefford, J. (1997). Multyvariate analysis of ecological data, vers 3.16 manual electrónico. MjM software, Gleneden Beach, Oregon.

Melo, A. (2008). Zonificación de los bosques de roble: una herramienta para la planificación del Ecosistema. Informe de gestión 2009 en el marco del proyecto "Corredor de conservación de robles, una estrategia para la conservación y el manejo forestal en Colombia". Bogotá: Fundación Natura. 45 p.

Ministerio de Ambiente, Vivienda y Desarrollo Territorial -MAVDT-. (2006). Resolución 096 del 20 de enero de 2006. Bogotá.

Rangel, J.O., \& Lozano, G. (1986). Un perfil de la vegetación entre la plata (Huila) y el volcán Puracé. Caldasia, 14 (68-70), 53-547.

Rangel, J.O., \& Garzón, C A. (1994). Aspectos de la estructura, de la diversidad y de la dinámica de la vegetación del Parque Regional Natural Ucumarí. En J.O. Rangel (ed.). Ucumarí: Un caso típico de la diversidad biótica andina (pp. 85-108). Pereira: Publicaciones de la Carder.

Rangel, J.O. (2000). La megadiversidad biológica de Colombia: ¿Realidad o ilusión? En J. Aguirre (ed). Memorias del Primer Congreso Colombiano de Botánica (Versión en CD-Rom) Bogotá. 
Rangel, J.O., Orjuela, M.A., Zambrano, H., \& Andrade, A. (2002). Generación de una propuesta de criterios e indicadores para implementar el enfoque ecosistémico en Colombia. En Proyecto "Generación de una propuesta metodológica y operativa que permita la adopción del enfoque ecosistémico en Colombia". Convenio 052-013/01 MAVDT-SECAB-Universidad Nacional de Colombia. Bogotá. 66 p.

Rangel, J.O., Cleef, A.M., Salamanca, S., \& Ariza, C.L. (2005). La vegetación de los bosques y selvas del Tatamá. En T. Van der Hammen, J.O. Rangel, \& A.M. Cleef (eds.). Estudios de Ecosistemas Tropandinos-Ecoandes 6. La cordillera Occidental, transecto de Tatamá (pp. 469-644). Berlín-Stuttgaart: J. Cramer, (Borntraeger).

Rangel, J.O. (2005). La biodiversidad de Colombia. Palimpsestos, 5, 292-304.

Rangel, J.O., Cleef, A.M., \& Arellano, H. (2008). La vegetación de los bosques y selvas del Transecto Sumapaz. En T. Van der Hammen (ed.). Estudios de Ecosistemas Tropandinos-Ecoandes 7. La cordillera Oriental colombiana, transecto Sumapaz (pp. 695-798). Berlín-Stuttgaart: J. Cramer.

Rangel, J.O., Avella, A., \& Garay, H. (2009). Caracterización florística y estructural de los relictos boscosos del sur del departamento del Cesar. En J.O. Rangel (eds.). Colombia diversidad biótica VIII. Media y baja montaña de la serranía del Perijá (pp. 365-392). Bogotá: Instituto de Ciencias Naturales, Universidad Nacional de Colombia, Corpocesar.
Rangel, J.O., \& Avella, A. (2011). Oak forests (Quercus humboldtii) in the Caribbean region and distribution patterns related with environmental factors in Colombia. Plant Biosystems, 145, 186-198.

Raymond, P. (1997). Hacienda tradicional y aparcería. Bucaramanga: Ediciones UIS. 360 p.

\section{Secretaría del Convenio de Diversidad Biológica} -SCDB- (2004). Enfoque por ecosistemas (directrices del CDB). Holanda: Secretaria del Convenio de Diversidad Biológica. 51 p.

Solano, C., Roa, C., \& Calle, Z. (2005). Estrategia de desarrollo sostenible del corredor de Conservación Guantiva-La Rusia-Iguaque. Bogotá: Fundación Natura. 87 p.

Solano, C. (2006). Reserva biológica Cachalú: 10 años de investigación en bosques de roble. En C. Solano, \& N. Vargas (eds.). Memorias del I Simposio Internacional de Robles y Ecosistemas Asociados (pp. 11-23). Bogotá: Fundación Natura, Pontificia Universidad Javeriana.

Van der Hammen, T. (2008). Zonal ecosystems of the western and eastern flanks of the Eastern cordillera of the Colombian Andes (Sumapaz Transect) En T. Van der Hammen (ed.). Estudios de Ecosistemas Tropandinos-Ecoandes 7. La cordillera Oriental colombiana, transecto Sumapaz (pp. 961-1009). Berlín-Stuttgaart: J. Cramer. 